\title{
Oxygen Consumption and Oxygen-Independence in Marine Crustaceans
}

\author{
C. R. Bridges* and A. R. Brand \\ Department of Marine Biology, University of Liverpool, Port Erin, Isle of Man, United Kingdom
}

\begin{abstract}
Weight-specific oxygen consumption $\left(\dot{V}_{2}\right)$ varied with body weight $(w)$ in four crustacean species investigated under comparable experimental conditions. The value of the exponent $b-1$ relating $\mathrm{VO}_{2}$ to body weight was significantly different $(P<0.01)$ in the burrowing crustaceans Corystes cassivelaunus and Nephrops norvegicus, compared to the nonburrowing anomurans, Galathea strigosa and Pagurus bernhardus. A mathematical transformation was used to provide an index $\left(K_{1} / K_{2}\right)$ of oxygen independence. Using this index it was found that oxygen independence was influenced by intrinsic factors (size and level of activity) and environmental factors (temperature and presence of substrate).
\end{abstract}

\section{INTRODUCTION}

Oxygen consumption in crustaceans has been the subject of many studies. For recent reviews consult 'Marine Ecology', Volume I: Segal, 1970, Kinne, 1970. 1971. In his review, Zeuthen (1953) used the results of Weymouth et al. (1944) to show that weight-specific oxygen consumption decreased with increasing body size. Other workers have found similar relationships for various crustaceans, e.g. Thomas (1954) for Homarus gammarus; Tashian (1956) for UCa spp., Wallace (1972), Klein Breteler (1975) and Taylor et al. (1977) for Carcinus maenas; Leffler (1973) for two species of xanthid crabs; Laird and Haefner (1976) for Callinectes sapidus and Shumway (1978) for Pagurus bernhardus. However, it is difficult to compare the values given in the literature for different species as different conditions were used by each worker. In the present study measurements were made of the effect of body size on the oxygen consumption of two burrowing, sublittoral crustaceans, Corystes cassivelaunus (Pennant) and Nephrops norvegicus (L.), and of two non-burrowing, sublittoral anomurans, Galathea strigosa (L.) and Pagurus bernhardus (L.) under comparable experimental conditions.

The effect of hypoxia on oxygen consumption has also received much attention, and differences in the ability to maintain oxygen consumption independent of the ambient oxygen tension during hypoxia have been found by various workers even for the same species (see Spoek, 1974 for review). More recently
Miller et al. (1976), Taylor (1976) and Taylor et al. (1977) have shown that the ability to regulate oxygen consumption may to some extent depend on the physiological state of the animal. Therefore, in this study, the oxygen consumption $\left(\mathrm{VO}_{2}\right)$ of Corystes cassivelaunus and Galathea strigosa was manipulated using intrinsic factors, size and level of activity, and environmental factors, temperature and the presence of a substrate, to determine the relationship between $\dot{\mathrm{VO}}_{2}$ levels, which are good indicators of the physiological state of the animal and the ability to maintain oxygen consumption independent of the ambient oxygen tension during hypoxia.

\section{MATERIALS AND METHODS}

Corystes cassivelaunus and Galathea strigosa were collected by diving in sublittoral areas around Port Erin, Isle of Man. Individuals of Nephrops norvegicus and Pagurus bernhardus were collected near Kristinebergs Marine Laboratory, Sweden, and experiments carried out on these two species at the Department of Zoophysiology, University of Aarhus, Denmark.

All crustaceans were kept for a period of at least 2 weeks in running seawater $\left(34 \% \mathrm{~S}, 10^{\circ} \mathrm{C}\right)$ under a 12

\footnotetext{
- Present address: Abteilung Physiologie, Max-PlanckInstitut für Experimentelle Medizin, Hermann-Rein-Straße 3, D-3400 Göttingen, Federal Republic of Gemnany.
} 
h dark: 12 h light environmental regime. The crustaceans were fed at regular intervals and starved for $2 \mathrm{~d}$ preceding an experiment. Only individuals in the hard intermoult $\left(\mathrm{C}_{4}\right)$ stage were used.

Measurements of oxygen consumption $\left(\mathrm{VO}_{2}\right)$ were made in both closed and flow-through perspex respirometers. Oxygen tensions were monitored using oxygen electrodes (Radiometer E 5046 and Yellow Springs Instruments 5331) either placed directly in the respirometer in the closed system or in a thermostatted cell. The respirometers were supplied with filtered seawater from a reservoir by means of an electric pump (T. E. P.). The temperature of the respirometers was maintained at $10^{\circ} \mathrm{C}$ for most experiments by a surrounding thermostatically controlled water bath. The oxygen electrodes were calibrated regularly with aerated seawater and zero $\mathrm{PO}_{2}$ solution. In the closed system a submersible magnetic stirrer prevented localised oxygen depletion around the electrodes. To record oxygen consumption in buried Corystes cassivelaunus a specially constructed respirometer was used which contained sterilised sand to a depth of $15 \mathrm{~cm}$ and a separate magnetic stirrer in a side tube to facilitate circulation within the respirometer.

\section{Measurements of Resting $\dot{\mathrm{V}} \mathrm{O}_{2}$}

To measure resting $\dot{\mathrm{VO}}_{2}$ in the closed system the crustacean was placed in a respirometer (volume $=1 \mathrm{l}$ ) and left for at least $12 \mathrm{~h}$ with aerated seawater flowing through the respirometer. The test animals were kept in dim red light and as free from external disturbances as possible. After this period of acclimation to experimental conditions to allow the adoption of a 'resting state', the respirometer was closed and the test animal allowed to deplete the oxygen content of the water in the respirometer. The respirometer was flushed, at hourly intervals, with aerated seawater and measurements were continued until a steady rate of oxygen consumption was observed over a number of hours. During these determinations $\mathrm{P}_{i} \mathrm{O}_{2}$ was not allowed to fall below 120 mm Hg.

For measurements of resting $\dot{\mathrm{VO}}_{2}$ in the flowthrough system either the oxygen tension of the water entering the respirometer $\left(\mathrm{P}_{\mathrm{N}} \mathrm{O}_{2}\right)$ or the oxygen tension of the water leaving the respirometer $\left(P_{O U T} \mathrm{O}_{2}\right)$ could be monitored by siphoning water past an electrode placed in a thermostatted cell at the same temperature as the respirometer. Flow through the whole system was adjusted so that an accurate determination of $\triangle P_{2}$, the difference between $\left(P_{I N} O_{2}\right)$ and $\left(P_{O U T} O_{2}\right)$, could be made without lowering significantly $(<120 \mathrm{~mm} \mathrm{Hg})$ the amount of oxygen available to the crustacean.
$\mathrm{PIN}_{\mathrm{IN}} \mathrm{O}_{2}$ was monitored at regular intervals together with flow through the system. Continuous recordings were made over periods of a number of days for each individual and resting $\mathrm{V}_{2}$ calculated. All experiments to determine resting $\mathrm{VO}_{2}$ were carried out at $10^{\circ} \mathrm{C}$ and $34 \% \mathrm{~S}$ in unburied test animals. The wet weights of all species were found by blotting dry with tissue and then weighing to $0.1 \mathrm{~g}$. For Corystes cassivelaunus individuals in the size range $4.8-24.5 \mathrm{~g}(n=11)$ were studied; for Galathea strigosa, 6.7-57.4 $\mathrm{g}(n=22)$; for Nephrops norvegicus, 41.8-206.8 $\mathrm{g}(\mathrm{n}=7)$ and for Pagurus bernhardus, $2.0-14.5 \mathrm{~g}(n=10)$.

\section{Oxygen Consumption During Hypoxia}

Recordings of oxygen consumption during hypoxia were made for Corystes cassivelaunus and Galathea strigosa, using two methods:

(1) The test animal, in a closed respirometer, was allowed to deplete the oxygen content to a low level over a period of time.

(2) The water in the closed respirometer was replaced at frequent intervals with water from the main reservoir which had been reduced to the required oxygen tension by bubbling nitrogen through it. This ensured that any accumulation of metabolites did not affect oxygen consumption. Both methods gave comparable results.

Levels of oxygen consumption were manipulated using four parameters:

(1) Body size. Individuals of Corystes cassivelaunus, and Galathea strigosa of different size were allowed to acclimate to experimental conditions under normoxia for $12 \mathrm{~h}$ and then subjected to hypoxia and oxygen consumption recorded.

(2) Activity induced by stress. Individuals of Corystes cassivelaunus and Galathea strigosa were placed in a respirometer and immediately subjected to hypoxia and their oxygen consumption monitored. In this stressed condition test animals showed increased locomotor activity. The crustaceans were then allowed to recover fully and to acclimate to experimental conditions under dim red light in normoxia before the oxygen content of the water was lowered progressively and oxygen consumption recorded again.

(3) Substrate. As Corystes cassivelaunus spends long periods buried in the sand, oxygen consumption during hypoxia was measured in the same individual, after acclimation to experimental conditions, held first in a clear respirometer and then buried in a sand-filled respirometer.

(4) Temperature. Measurements of oxygen consumption during hypoxia were made at $7^{\circ}, 11^{\circ}$ and $15^{\circ} \mathrm{C}$ in Galathea strigosa after acclimation to experimental 
temperatures for at least 2 weeks and to experimental conditions for $12 \mathrm{~h}$ before lowering $\mathrm{P}_{\mathrm{T}} \mathrm{O}_{2}$.

At the beginning and end of each series of experiments blank runs were made with empty respirometers to determine any background microbial respiration; this was found to be negligible.

\section{RESULTS}

\section{Relationship Between Oxygen Consumption and Wet Weight in Marine Crustaceans}

The relationship between wet weight $(w)$ and resting weight specific oxygen consumption $\left(\mathbf{V O}_{2}\right)$ determined for each of the four species used in this study is shown in Figure 1. Regression lines were fitted to the data for each species using the general expression:

$$
\dot{\mathrm{V}} \mathrm{O}_{2}=a w^{b-1}
$$

The following expressions were derived:

Corystes cassivelaunus

$\begin{array}{lll} & \dot{V O}_{2}=0.024 w^{-0.123}(r=-0.85) \\ \text { Galathea strigosa } & \dot{V O}_{2}=0.051 w^{-0.264}(r=-0.89) \\ \text { Nephrops norvegicus } & \dot{V O}_{2}=0.037 w^{-0.139}(r=-0.99) \\ \text { Pagurus bernhardus } & \dot{V O}_{2}=0.070 w^{-0.247}(r=-0.95)\end{array}$

The overall values for $\dot{\mathrm{VO}}_{2}$ were found to be lowest in $C$. cassivelaunus and highest in $P$. bernhardus and similar values for $\mathrm{VO}_{2}$ were found from flow-through and closed respirometry for the same test animal. In all species it was found that resting or inactive weight specific oxygen consumption decreased with increasing weight or size. The slopes of the regression lines for $C$. cassivelaunus and $N$. norvegicus, were both significantly different from those of $G$. strigosa and $P$. bernhardus, at the $P<0.01$ level.

\section{Effect of Intrinsic and Environmental Factors on the Ability to Regulate Oxygen Consumption During Hypoxia in $C$. cassivelaunus and $G$. strigosa}

\section{Body Size}

When the resting or inactive level of oxygen consumption was measured during hypoxia in two Corystes cassivelaunus of differing size (Fig. 2), both individuals were able to maintain their oxygen consumption at a more or less constant level down to the critical oxygen tension $\left(P_{C}\right.$.). When this level is reached, $\mathbf{V O}_{2}$ becomes dependent on the external oxygen tension and declines. Only values obtained during the regulatory phase were used in the previous determination of the effect of size on resting weight-specific oxygen consumption. Similar determinations of $\mathrm{VO}_{2}$ in resting Galathea strigosa during hypoxia (Fig. 3) showed that

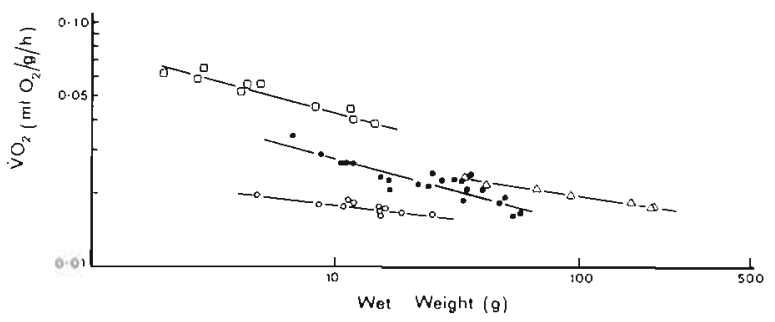

Fig. 1 Relationship between weight-specific oxygen consumption $\left(\mathrm{VO}_{2}\right)$ and wet weight for: Corystes cassivelaunus

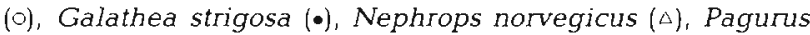
bernhardus ( 0 ). Plotted on a $\log$-log basis; regression line shown

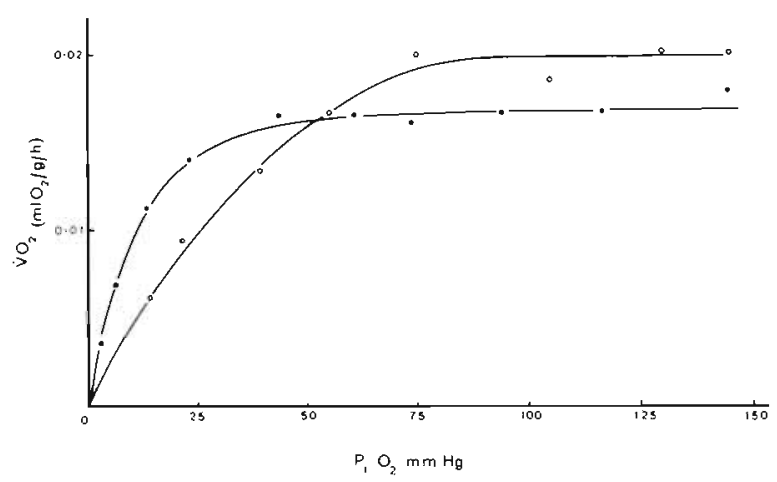

Fig. 2. Corystes cassivelaunus. Weight-specific oxygen consumption $\left(\mathrm{V}_{2}\right)$ of two individuals during declining $\mathrm{P}_{\mathrm{i}} \mathrm{O}_{2}$. $4.8 \mathrm{~g}$ individual (o), $18.1 \mathrm{~g}$ individual (•)

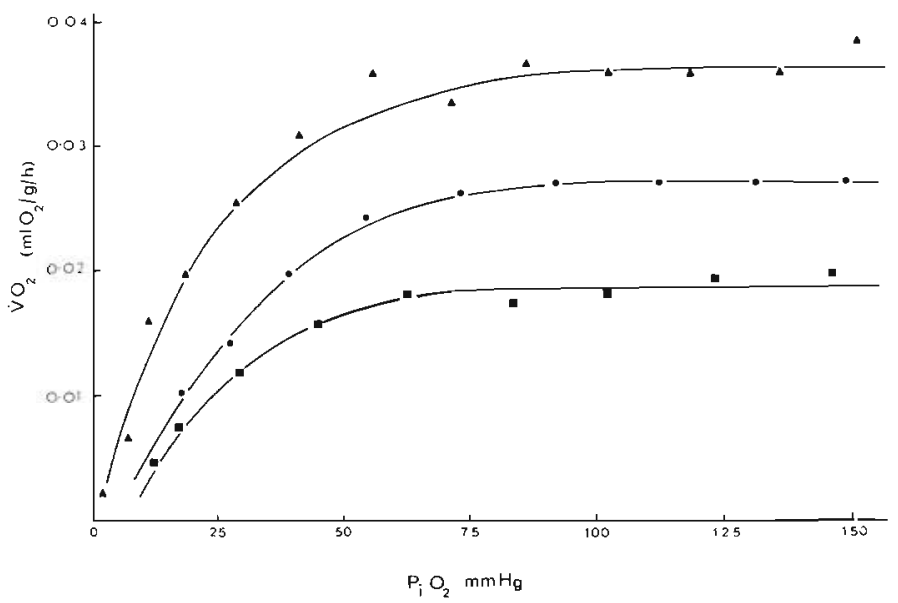

Fig. 3. Galathea strigosa. Weight-specific oxygen consumption $\left(\mathrm{VO}_{2}\right)$ of three individuals during declining $P_{1} O_{2} .6 .7 \mathrm{~g}$ individuals (^), $11.8 \mathrm{~g}$ individual $(\bullet), 47.3 \mathrm{~g}$ individual (•)

this species was also able to regulate oxygen consumption. Regulatory ability appeared to vary with size in both species. The critical oxygen tension $(P C)$ is a difficult criteria to assess accurately as a specific point for each individual, therefore, to compare the regulatory ability of individuals of varying size, a method derived by Tang (1933) was used to transform the 
graphs relating $\mathrm{V}_{2}$ to oxygen tension into a linear form. Thus by plotting $\mathrm{PO}_{2} / \mathrm{V}_{2}$ against $\mathrm{PO}_{2}$, the oxygen consumption curve is usually transformed into a straight line and two constants $K_{1}$ the intercept, and $K_{2}$, the slope of the regression line, are derived. Using this method, Bayne (1971) and Taylor and Brand (1975) obtained the index $K_{1} / K_{2}$ which describes the degree of respiratory independence shown by the test animal. Increasing values for the index indicate a decrease in regulatory ability.

The regulatory ability of Corystes cassivelaunus of differing size was examined using this Tang transformation and as $\mathrm{VO}_{2}$ increases with decreasing size (Fig. 1) $\dot{\mathrm{V}}_{2}$ was plotted against the $K_{1} / K_{2}$ index for each individual (Fig. 4). A regression analysis of the data gave the following expression:

$\dot{\mathrm{V}}_{2}=0.011 K_{1} / K_{2}^{0.140} \quad(n=12, r=0.75)$ An analysis for the data obtained for Galathea strigosa (Fig. 4) gave the following expression:

$\dot{\mathrm{V}}_{2}=0.011 K_{1} / K_{2}^{0.234} \quad(n=24, r=0.751)$ In both species the slopes of the regression lines had positive values and were significantly different at $P<0.05$ from zero (shown by the slope of the dotted line in Fig. 4). This indicates that with increasing size the $K_{1} / K_{2}$ index decreased.

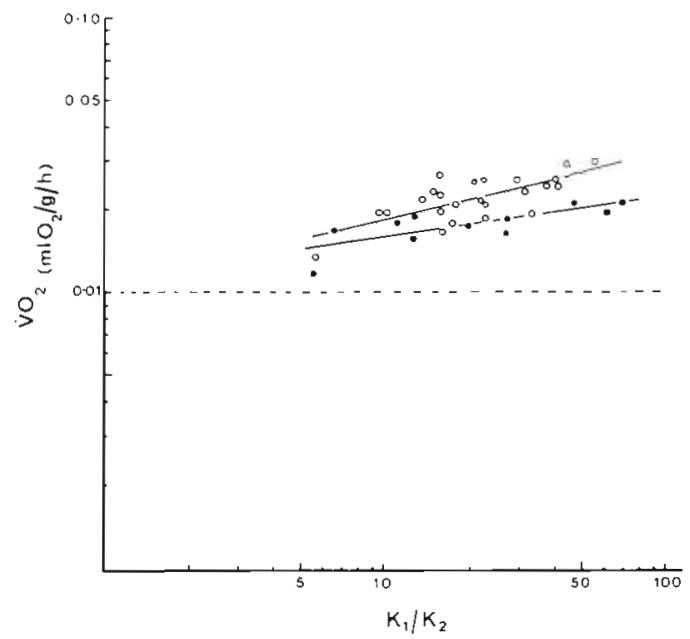

Fig. 4. Corystes cassivelaunus $(\bullet)$ and Galathea strigosa (0). Relationship between weight-specific oxygen consumption $\left(\mathrm{VO}_{2}\right)$ and oxygen dependence index $K_{1} / K_{2}$. Regression lines shown; broken line slope $=$ zero

\section{Activity Induced by Stress}

Figures 5 and 6 show the typical responses of individuals of Corystes cassivelaunus and Galathea strigosa, in both the stressed and resting state. Oxygen consumption in the active stressed individual is elevated above the values of the resting individual at high $P_{i} O_{2}$. Depending upon the degree of activity and stress, this level may represent the maximum sustainable level of respiration for that individual. In the resting individual oxygen consumption is maintained at a constant level during hypoxia, until the $P_{C}$ is reached. In the active individual oxygen consumption is not maintained at a constant level and declines with falling oxygen tension. This loss of regulatory ability is illustrated by the values of the $K_{1} / K_{2}$ index for $C$. cassivelaunus in the two different states. In the resting individual $K_{1} / K_{2}$ was 8.0 compared with 22.5 in the active state. In G. strigosa the corresponding values were 18 and 174 for the resting and active states, respectively.

\section{Substrate}

Corystes cassivelaunus is able to maintain oxygen consumption independent of falling oxygen tensions when buried in sand in the respirometer or exposed in a respirometer with no sand. Figure 7 shows the typical response of the same individual subjected to hypoxia in a respirometer with and without sand. There is a marked difference in the level at which $\mathrm{VO}_{2}$ is maintained between the buried and unburied individual. In general there was a $40-60 \%$ reduction in oxygen consumption in buried individuals. The effect on regulatory ability was not marked with a $K_{1} / K_{2}$ value of 4.7 in the buried state, compared with 9.2 in the exposed state. It is interesting to note that in the buried state $\mathrm{VO}_{2}$ tended to zero before $P_{i} \mathrm{O}_{2}$ reached zero.

\section{Temperature}

Typical recordings of oxygen consumption of Galathea strigosa during hypoxia at $7^{\circ}, 11^{\circ}$ and $15^{\circ} \mathrm{C}$ are shown in Figure 8. As would be expected there was an increase in the level at which $\mathrm{VO}_{2}$ was maintained with increasing temperature. The $Q_{10}$ values calculated for the temperatures used were as follows:

$$
\begin{aligned}
7^{\circ}-11^{\circ} \mathrm{C} & =3.41 \\
11^{\circ}-15^{\circ} \mathrm{C} & =3.71
\end{aligned}
$$

The effect on regulatory ability is shown by the increase in the $K_{1} / K_{2}$ index with increasing temperature. At $7^{\circ} \mathrm{C}$ the value for the $K_{1} / K_{2}$ index is 11.8 compared to 18.8 at $11{ }^{\circ} \mathrm{C}$ and 43.0 at $15^{\circ} \mathrm{C}$.

\section{DISCUSSION}

It is well known in respiratory physiology that oxygen consumption can be affected by both intrinsic and environmental factors (Dejours, 1975). This study set out to examine the relationship between size, an intrinsic factor, and resting weight-specific oxygen 


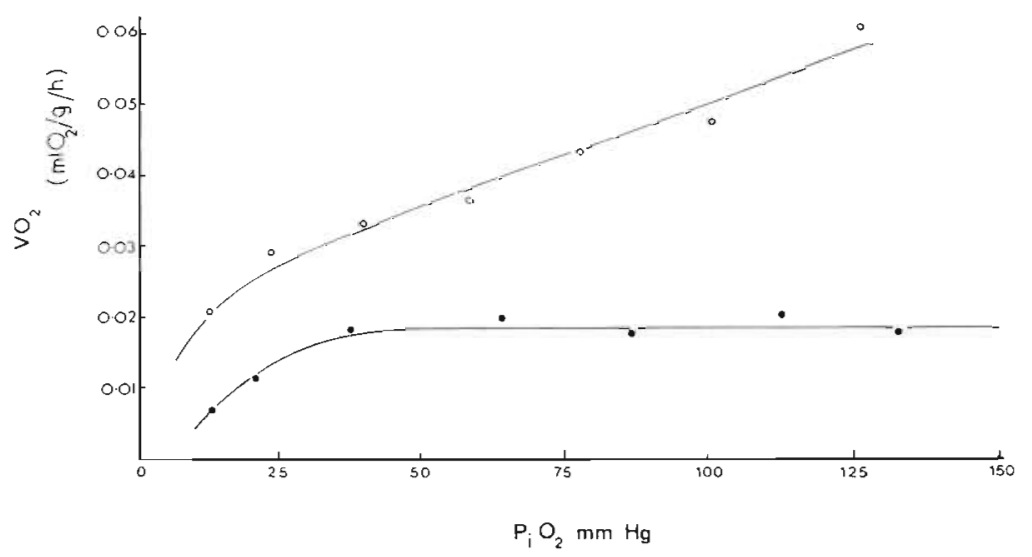

Fig. 5. Corystes cassivelaunus. Weight-specific oxygen consumption $\left(\mathrm{V}_{2}\right)$ of a $15.1 \mathrm{~g}$ individual exposed to declining oxygen tension. Upper curve: active state $K_{1} / K_{2}=22$; lower curve: resting inactive state $K_{1} / K_{2}=8$

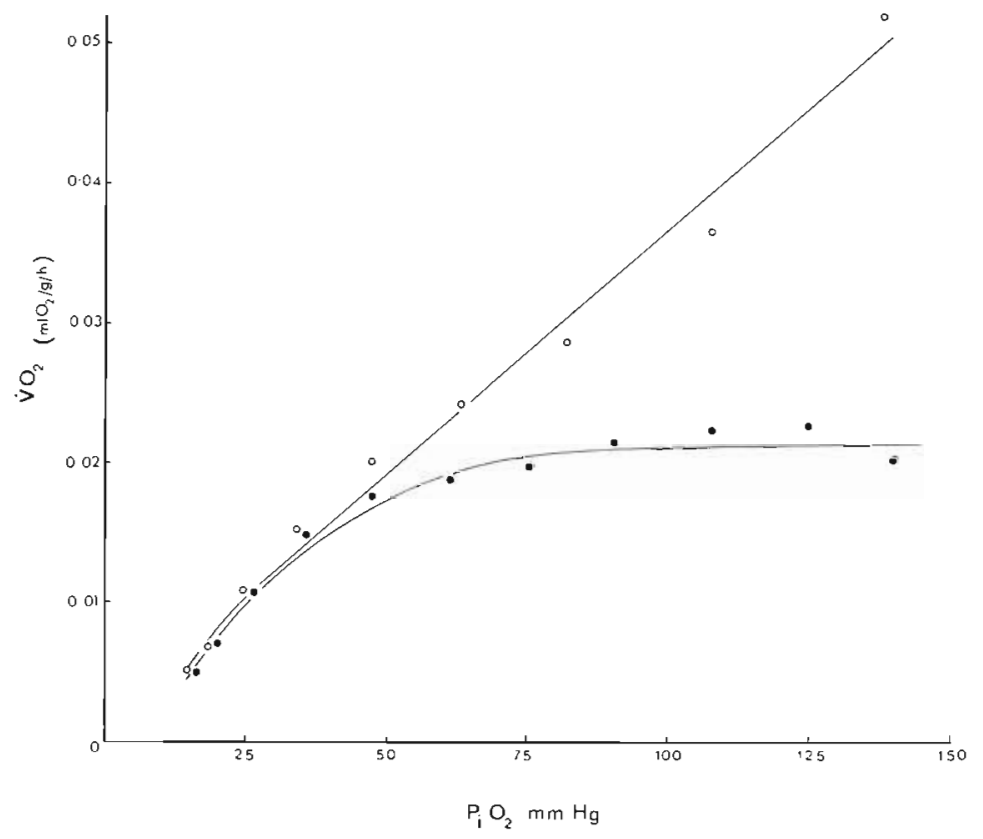

Fig. 6. Galathea strigosa. Weight-specific oxygen consumption $\left(\mathrm{VO}_{2}\right)$ of a $22.2 \mathrm{~g}$ individual exposed to declining oxygen tension. Upper curve: active state $K_{1} / K_{2}=174$; lower curve: resting inactive state $K_{1} / K_{2}=18$

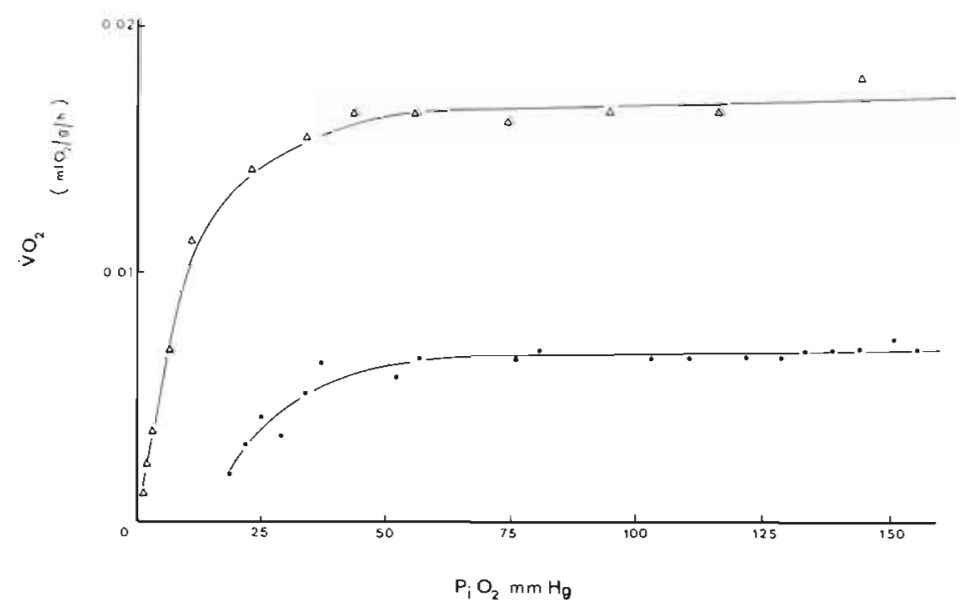

Fig. 7. Corystes cassivelaunus. Weight-specific oxygen consumption $\left(\mathrm{V}_{2}\right)$ of a $18.1 \mathrm{~g}$ individual exposed to declining oxygen tension. Upper curve: exposed in a clear respirometer $K_{1} / K_{2}=9.2$; lower curve: buried under sand $K_{1} / K_{2}=4.7$ 


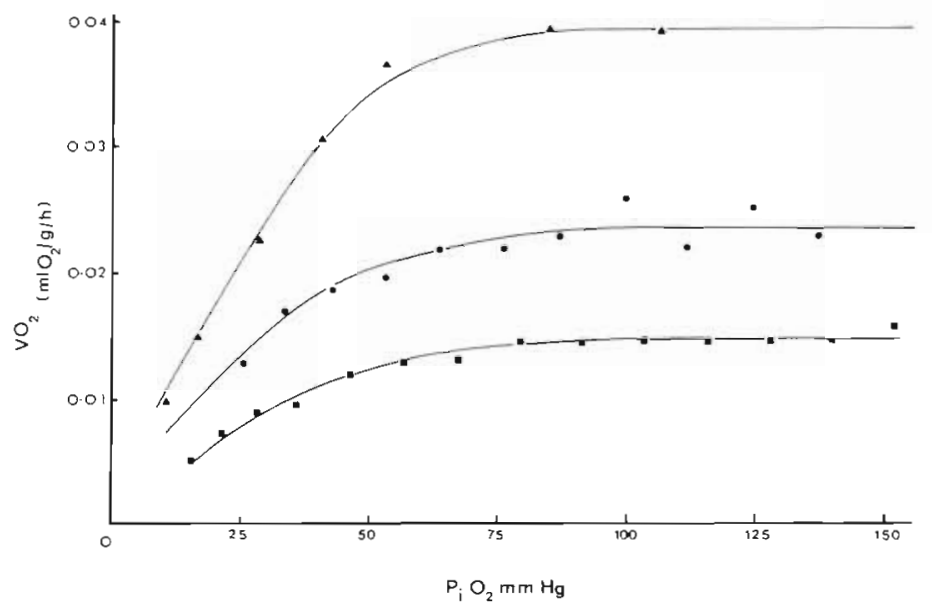

Fig. 8. Galathea strigosa. Weight-specific oxygen consumption $\left(\mathrm{VO}_{2}\right)$ of a $21.9 \mathrm{~g}$ individual exposed to declining oxygen tension after acclimation to three different temperatures. Upper curve: $15^{\circ} \mathrm{C}, K_{1} / K_{2}=43$; middle curve: $11^{\circ} \mathrm{C}, K_{1} / K_{2}=18.9$; lower curve: $7{ }^{\circ} \mathrm{C}, K_{1} / K_{2}=11.8$

Table 1. Relationship between $\dot{\mathrm{VO}}_{2}$ and body weight in decapod crustaceans

\begin{tabular}{|c|c|c|c|c|c|}
\hline Species & $\begin{array}{l}\text { Wet weight } \\
\text { range }(\mathrm{g})\end{array}$ & $\begin{array}{c}\text { Temperature } \\
\left({ }^{\circ} \mathrm{C}\right)\end{array}$ & $\begin{array}{l}\dot{\mathrm{VO}_{2}}=a w^{b-1} \\
\left(\mathrm{mlO}_{2} \mathrm{~g}^{-1} h^{-1}\right\}\end{array}$ & $b$ & Reference \\
\hline Panulirus interruptus & -393.6 & 13 & $0.602 w^{-0.513}$ & 0.487 & Winget (1969) \\
\hline Panulinus japonicus & $25.5-35.3$ & 17.8 & $0.050 w^{-0.163}$ & 0.837 & Nimura \& Inoue (1969) \\
\hline Homarus americanus & $0.9-12.300$ & 15 & $0.073 w^{-0.130}$ & 0.870 & McLeese (1964) \\
\hline Homarus gammarus & $330-770$ & 15 & $1.357 w^{-0.512}$ & 0.482 & Thomas (1954) \\
\hline Nephrops norvegicus & $41.8-206.8$ & 10 & $0.037 w^{-0139}$ & 0.861 & This study \\
\hline Orconectes immunis & $1.8-8.37$ & 16 & $0.110 w^{-0.292}$ & 0.708 & Wiens \& Armitage (1961) \\
\hline Orconectes nais & $1.8-8.37$ & 16 & $0.117 w^{-0.356}$ & 0.644 & Wiens \& Armitage (1961) \\
\hline Galathea strigosa & $6.7-57.4$ & 10 & $0.051 w^{-0.254}$ & 0.736 & This study \\
\hline Pagurus bernhardus & $2.0-14.7$ & 10 & $0.070 w^{-0.247}$ & 0.753 & This study \\
\hline Carcinus maenas & $0.2-24$ & 15 & $0.123 w^{-0.486}$ & 0.514 & Wallace (1972) \\
\hline Carcinus maenas & $27-95$ & 15 & $0.030 w^{-0.200}$ & 0.800 & Taylor et al. (1977) \\
\hline Corystes cassivelaunus & $4.8-24.5$ & 10 & $0.024 w^{-0.123}$ & 0.877 & This study \\
\hline Hemigrapsus oregonensis & $0.4-5.0$ & 15 & $0.090 w^{-0.714}$ & 0.286 & Dehnel (1958) \\
\hline Pachygrapsus crassipes & $3.05-32.65$ & 8.5 & $0.036 w^{-0.335}$ & 0.665 & Roberts (1957) \\
\hline Pugettia producta & $1.64-329$ & 15 & $0.170 w^{-0.202}$ & 0.798 & Weymouth et al. (1944) \\
\hline Uca pugnax & $0.02-8.32$ & 14 & $0.068 w^{-0235}$ & 0.765 & Tashian (1956) \\
\hline Average of 54 crustaceans & $0.05-700$ & 15 & $0.108 w^{-0.150}$ & 0.850 & Weymouth et al. (1944) \\
\hline
\end{tabular}

consumption under comparable experimental conditions, for four crustaceans from different ecological niches.

Zeuthen (1953) suggested that the total metabolism of a metazoan is related to their total cell-surface area and hence metabolism varies with the 0.67 power of the body weight. However, Hemmingsen $(1950,1960)$ found that metabolism varies more with the 0.75 power of the body weight as additional factors such as internal convection, vascularisation and the development of complex respiratory exchange surfaces also affect metabolism. All four crustaceans used in the present study showed values of $b$ either equal to or greater than 0.75 . Interspecific differences in the value for $b$ for a number of crustaceans are shown in Table 1 . The values listed range from $0.286-0.877$ for a temperature range of $8.5^{\circ}-17.8^{\circ} \mathrm{C}$, although Rao (1958) and Childress (1971) working at temperatures outside this range reported values for $b$ of 1.0 for Metapenaeus monoceros and Gnathophausia ingens, respectively. However, the majority of crustaceans have values for $b<1.0$. Low values of $b<0.67$ can usually be explaineds by different activity states of individuals pooled to give measurements (Thomas, 1954; Dehnel, 1958) or the sample size being too small (Winget, 1969). One overall trend which is apparent is that the crustaceans with the larger weight ranges tend towards a value of $b$ $>0.75$. This may indicate that oxygen consumption is 
more dependent on mass in the larger animals as a greater proportion of the total mass may be used for structural support, i. e. the carapace. Corystes cassivelaunus is an exception to this general trend but shows reduced metabolism under certain conditions and this may affect the value of $b$.

In the present study, it is evident that under the same experimental conditions $b$ was significantly higher in the burrowing species compared to the non-burrowing species. The general levels of oxygen consumption appear to be lower in the burrowing crustaceans compared to the non-burrowing species. This factor may be correlated with the more sedentary life of the burrowing forms compared to the more exposed life of the anomurans which are capable of rapid escape movements. As stated earlier, higher activity levels tend to depress $b$ and Klein Breteler (1975) suggests that discrepancies in values of $b$ in Carcinus maenas are due to experimental techniques causing increased activity. No comparative values of $b$ are available in the literature for Corystes cassivelaunus, Galathea strigosa and Nephrops norvegicus, but Shumway (1978) using dry weight, $15^{\circ} \mathrm{C}$ and smaller individuals reported a value of $b=0.665$ for Pagurus bernhardus compared with 0.753 in the present study. This discrepancy is probably due to the small size of the individuals used in Shumway's study, as at the small size range $b$ tends towards 0.67 . The crustaceans in the present study were also probably at a lower activity level, as overall $\mathrm{VO}_{2}$ levels in Shumway's study are high compared to those in the present study.

Since activity state, nutrition and developmental stage were controlled to some extent in the present study, the observed differences in $b$ between the burrowing and non-burrowing crustaceans may be correlated with other factors. Dejours (1975) and Hughes (1977) review the relationship between respiratory characteristics and body size. Both authors emphasize the value of comparisons between gill surface area, oxygen consumption and body mass. It is therefore interesting to note that the mean gill-surface area to body-weight ratio is lower in Nephrops norvegicus compared to Pagurus bernhardus (Scammell, 1971). Corystes cassivelaunus shows low levels of oxygen consumption, as in $N$. norvegicus, but has approximately the same gill surface area to body-weight ratio as $P$. bernhardus which has high levels of oxygen consumption. This anomaly may be explained because $C$. cassivelaunus is an atypical crustacean in that a cocurrent gas exchange system may function in this species (Bridges, 1976) thereby requiring a greater gill surface area. Belman and Childress (1976) reported a large gill surface area relative to oxygen consumption in Gnathophausia ingens as a mechanism to increase oxygen diffusion across the gills, as this species inhab- its deep-water zones of oxygen depletion. Gray (1957) showed that gill surface area was higher in the more active crabs compared to the more sedentary slowmoving species and both Gray (1957) and Scammell (1971) found that weight-specific gill area decreased with increasing body size in the species they studied. In fish Hughes $(1972,1977)$ found differences in the ratio of the exponent relating body mass to metabolism and gill area for different species. It is probable that a similar comparison for crustaceans would also reveal differences in this ratio. How far the relationship between gill surface area, body mass and oxygen consumption interact is not fully understood, but since crustaceans possess limited facilities for cutaneous gas exchange due to their carapace, such an interaction may be one of a number of intrinsic factors influencing oxygen consumption.

The second part of this study deals with the interaction of environmental and intrinsic factors with the ability to maintain oxygen consumption independent of falling oxygen tensions. Dejours (1975) states 'If animals maintain their energy metabolism within a more or less broad range of environmental oxygenation, they are oxygen independent; if not, they are oxygen-dependent'. Tang (1933) and Mangum and Van Winkle (1973) have attempted to quantify the ability to maintain oxygen-independence in various animals using the hyperbolic and the quadratic relationship, respectively. The Tang transformation is difficult to apply when oxygen-independence approaches a linear function and the quadratic expression has difficulties when oxygen-independence is near perfect. Both expressions may be affected by other factors, and it is unlikely that any one expression would be able to satisfy the full range of the data found in respiratory regulation. As the data in this study approximate the conditions for the hyperbolic fit, with an upper asymptote and the curve passing through $(x$, $y)=(0,0)$, the Tang transformation has been used to give some quantitative value to regulatory ability with changes in $\dot{\mathrm{VO}}_{2}$ levels. Previous workers have, however, either delineated a fixed point (Childress, 1971; Spoek, 1974; Taylor et al., 1977) or a range (Thompson and Pritchard, 1969; Taylor, 1976) for the critical oxygen tension. Corystes cassivelaunus and Galathea strigosa both show oxygen-independence but this ability is more developed in the former. For same-sized individuals the $K_{1} / K_{2}$ index is lower in C. cassivelaunus than in $G$. strigosa. This can be correlated with the lower $\mathrm{VO}_{2}$ level for a given individual size in $C$. cassivelaunus (Fig. 1). The lower PC level in C. cassivelaunus is probably an adaptation to low environmental oxygen tensions as shown by a number of crustaceans, e. g. Orconectes sp. (Wiens and Armitage, 1961), CaIlianassa californiensis (Thompson and Pritchard, 1969) 
and in mid-water crustaceans living in oxygen depleted zones (Childress, 1971, 1975). Oxygen-independence is significantly correlated with $\mathrm{VO}_{2}$ in both species and a similar regression analysis for $K_{1} / K_{2}$ against weight gave a negative slope which was significantly different from zero for both $C$. cassivelaunus and $G$. strigosa. This indicates that larger individuals are better able to maintain their oxygen-independence during hypoxia than smaller individuals. Although Job (1955) states that there seems to be no relationship between body size and $P_{C}$ in fish there is evidence that this is not the case in invertebrates. Bayne (1971) and Taylor and Brand (1975) found an increase in the ability of marine bivalve molluscs to maintain oxygenindependence with increasing size during hypoxia. Childress (1971) found that in the crustacean Gnathophausia ingens there was an increase in $P_{C}$ with increasing $\mathrm{VO}_{2}$.

Activity has a dramatic effect on oxygen-independence as shown by the large difference in the $K_{1} / K_{2}$ values between the active and inactive states for Corystes cassivelaunus and Galathea strigosa. This difference is due to the elevated levels of $\mathrm{VO}_{2}$ in the active state at high $\mathrm{P}_{\mathrm{i}} \mathrm{O}_{2}$. McLeese (1964), Nimura and Inoue (1969), Spoek (1974) and Taylor (1976) all found decreases in oxygen-independence with increased activity. An increase in acclimation temperature also induces a rise in the $\mathrm{VO}_{2}$ levels and a corresponding increase in the $K_{1} / K_{2}$ index for $G$. strigosa. Wiens and Armitage (1961) and Taylor et al. (1977) both found a decrease in oxygen-independence with increasing temperature and this has been confirmed in this study.

Corystes cassivelaunus spends long periods buried in the substrate and the decrease in $\mathrm{VO}_{2}$ levels in the buried state compared to the unburied state indicates an energy-conserving strategy in which metabolism is reduced, for $C$. cassivelaunus shows long periods of apnoea and bradycardia when buried (Bridges, 1979). De Wilde (1973) documented reduced levels of oxygen consumption in buried bivalves, and Johansen and Petersen (1975) found a similar reduction in $\dot{\mathrm{VO}}_{2}$ in buried horseshoe crabs. The failure to consume oxygen down to zero $P_{\mathrm{i}} \mathrm{O}_{2}$ in $\mathrm{C}$. cassivelaunus when buried may indicate a change to full anaerobic metabolism. This may be linked with the ability of C. cassivelaunus to accumulate lactate, an important anaerobic endproduct in crustaceans, during exposure to hypoxia and then rapidly remove it on return to normoxia (Bridges and Brand, 1979). The small change in the $K_{1} /$ $K_{2}$ index between buried and unburied state indicates that the hyperbolic fit of the Tang transformation may be less applicable when the curve does not pass through $(x, y)=(0,0)$.

From the evidence presented in this study and in the literature it is clear that increases or decreases in resting $\dot{\mathrm{VO}}_{2}$ levels by intrinsic and environmental factors influence the ability to maintain oxygen consumption independent of oxygen tension during hypoxia. This correlation may be explained in terms of the limitations of the gas exchange system of the organism as suggested by Fry (1957) and Hughes (1964) for fish. Normally, $\mathrm{V}_{2}$ is maintained oxygen-independent by adjustments of the gas exchange system of the organism to provide the tissues with the same amount of oxygen from a decreasing external supply. However, an external oxygen tension is reached, the $P_{C}$, below which the limitations of the gas exchange system prevent the continued maintenance of $\mathrm{VO}_{2}$ at a constant level, as further adjustments of the gas exchange system would only serve to supply the increased oxygen demand of the respiratory pumps themselves and oxygen consumption becomes dependent on the external oxygen tension. It can be seen, therefore, that the higher the resting $\dot{\mathrm{VO}}_{2}$ level, due to intrinsic and environmental factors, the higher will be the level of the external oxygen tension at which the limitations of the gas-exchange system become apparent and oxygen demand cannot be satisfied.

Acknowledgements. Thanks are due to Professor E. Naylor for providing encouragement for this work and to the staff of the Dept of Marine Biology, Port Erin, the staff of Kristinebergs Marinbiologiska Station, Sweden and the Dept of Zoophysiology, University of Aarhus, Denmark for providing experimental animals and facilities. C.R.B. received financial support from the S.R.C. and the Royal Society during the course of this work.

\section{LITERATURE CITED}

Bayne, B. L. (1971). Oxygen consumption by three species of lamellibranch mollusc in declining ambient oxygen tension. Comp. Biochem. Physiol. 40 A: 955-970

Belman, B. W., Childress, J. J. (1976). Circulatory adaptations to the oxygen minimum layer in the bathypelagic mysid, Gnathophausia ingens. Biol. Bull. mar. biol. Lab., Woods Hole 150: 15-37

Bridges, C. R. (1976). A study of the respiratory physiology of Galathea strigosa (L.) and Corystes cassivelaunus (Pennant). Ph. D. thesis, University of Liverpool

Bridges, C. R. (1979). Adaptations of Corystes cassivelaunus to an arenicolous mode of life. In: Naylor, E., Hartnoll, R. G. (eds) Cyclic phenomena in marine plants and animals. Pergamon Press, Oxford. pp. 317-324. (Proc. 13th Europ Mar. Biol. Symp.)

Bridges, C. R., Brand, A. R. (1979). The effect of hypoxia on oxygen consumption and blood lactate levels of some marine Crustacea. Comp. Biochem. Physiol., in press.

Childress, J. J. (1971). Respiratory adaptations to the oxygen minimum layer in the bathypelagic mysid Gnathophausia ingens. Biol. Bull mar. biol. Lab., Woods Hole 141: 109-121

Childress, J. J. (1975). The respiratory rates of mid-water crustaceans as a function of depth of occurrence and relation to the oxygen minimum layer off Southern California. Comp. Biochem. Physiol. 50 A: 787-799 
Dehnel, P. A. (1958). Effect of photoperiod on the oxygen consumption of two species of intertidal crabs. Nature, Lond. 181: 1415-1417

Dejours, P. (1975). Principles of comparative respiratory physiology, Elsevier/North-Holland, Amsterdam

Fry, F. E. J. (1957). The aquatic respiration of fish. In: Brown, M. E. (ed.) The physiology of fishes, Vol. 1. Academic Press, New York. pp. 1-63

Gray, I. E. (1957). A comparative study of gill area of crabs. Biol. Bull. mar biol. Lab., Woods Hole 112: 34-42

Hemmingsen, A. M. (1950). The relation of standard (basal) energy metabolism to total fresh weight of living organisms. Rep. Steno meml Hosp. 4: 7-58

Hemmingsen, A. M. (1960). Energy metabolism as related to body size and respiratory surfaces and its evolution. Rep. Steno meml Hosp. 9, 7-110

Hughes, G. M. (1964). Fish respiratory homeostasis. Symp. Soc. exp. Biol. 18: 81-97

Hughes, G. M. (1972). Morphometrics of fish gills. Respir Physiol. 14: 1-25

Hughes, G. M. (1977). Dimensions and the respiration of lower vertebrates. In: Pedley, T. J. (ed.) Scale effects in animal locomotion. Academic Press, London, pp. 57-81.

Job, S. V (1955). The oxygen consumption of Salvelinus fontinalis. Univ. Toronto Biol. Ser. No. 61, Publs Ontario Fish. Res. Lab. LXXIII: 1-39

Johansen, K., Petersen, J. A. (1975). Respiratory adaptations in Limulus polyphemus. In: Vernberg, F. J. (ed.) Ecophysiology of estuarine organisms. University South Carolina Press, Columbia, S. C, pp. 129-145

Kinne, O. (1970). Temperature: animals: invertebrates. In: Kinne, O. (ed.) Marine ecology, Vol. I, Environmental factors, Part 1. Wiley, London, pp. 407-514

Kinne, O. (1971). Salinity: animals: invertebrates. In: Kinne, O. (ed.) Marine ecology, Vol. I, Environmental factors, Part 2. Wiley, London, pp. 821-995

Klein Breteler, W. C. M. (1975). Oxygen consumption and respiratory levels of juvenile shore crabs, Carcinus maenas, in relation to weight and temperature. Neth. J. Sea. Res. 9: 243-254

Laird, C. E., Haefner, P. A. (1976). The effect of intrinsic and environmental factors on oxygen consumption in the blue crab, Callinectes sapidus (Rathbun). J. exp. mar. Biol. Ecol. 22: 171-178

Leffler, C. W. (1973). Metabolic rate in relation to body size and environmental oxygen concentration in two species of xanthid crabs. Comp. Biochem. Physiol. 44 A: 1047-1052

Mangum, C. P., Van Winkle, W. (1973). Responses of aquatic invertebrates to declining oxygen conditions. Am. Zool. 13: $529-541$

McLeese, D. W. (1964). Oxygen consumption of the lobster Homarus americanus. Helgoländer wiss. Meeresunters. 10: $7-18$

Miller, K. I., Pritchard, A. W., Rutledge, P. S. (1976). Respiratory regulation and the role of the blood in the burrowing shrimp Callianassa califormiensis (Decapoda: Thalassinidea). Mar. Biol. 36: 233-242

Nimura, Y., Inoue, M. (1969). Oxygen uptake rate of the Japanese spiny lobster as related to the environmental oxygen concentration. Bull. Jap. Soc. scient. Fish. 35: $852-861$

Rao, K. P. (1958). Oxygen consumption as a function of size and salinity in Metapenaeus monoceros Fab. from marine and brackish-water environments. J. exp. Biol. 35: $307-313$

Roberts, J. L. (1957). Thermal acclimation of the metabolism in the crab Pachygrapsus crassipes (Randall). I. The influence of body size, starvation and moulting. Physiol. Zoöl. 30: $232-242$

Scammell, C. A. (1971). Respiration and its nervous control in the shore crab, Carcinus maenas (Leach) including a comparative study of functional respiratory morphology in decapod crustaceans. Ph. D. thesis, University of Bristol

Segal, E. (1970). Light: animals: invertebrates. In: Kinne, O. (ed.) Marine ecology, Vol. I, Environmental factors, Part 2. Wiley, London, pp. 159-211

Shumway, S. E. (1978). Osmotic balance and respiration in the hermit crab, Pagurus bernhardus, exposed to fluctuating salinities. J. mar biol. Ass. U. K. 58: 869-876

Spoek, G. L. (1974). The relationship between blood haemocyanin level, oxygen uptake, and the heart-beat and scaphognathite-beat frequencies in the lobster Homarus gammarus. Neth. J. Sea Res. 8: 1-26

Tang, P. S. (1933). Oxygen consumption as a function of oxygen pressure. Q. Rev. Biol. 8: 260-274

Tashian, R. E. (1956). Geographic variation in the respiratory metabolism and temperature coefficient in tropical and temperate forms of the fiddler crab Uca pugnax. Zoologica, N. Y. 41: 39-47

Taylor, A. C. (1976). The respiratory responses of Carcinus maenas to declining oxygen tension. J. exp. Biol. 65 : 309-322

Taylor, A. C., Brand, A. R. (1975). Effects of hypoxia and body size on the oxygen consumption of the bivalve Arctica islandica L. J. exp. mar. Biol. Ecol. 19: 187-196

Taylor, E. W., Butler, P. J., Al-Wassia, A. (1977). Some responses of the shore crab Carcinus maenas (L.) to progressive hypoxia at different acclimation temperatures and salinities. J. comp. Physiol. 122: 391-402

Thomas, H. J. (1954). The oxygen uptake of the lobster Homarus vulgaris Edw. J. exp. Biol. 31: 228-251

Thompson, R. K., Pritchard, A. W. (1969). Respiratory adaptations of the two burrowing crustaceans, Callianassa californiensis and Upogebia pugettensis (Decapoda: Thalassinidae). Biol. Bull. mar. biol. Lab., Woods Hole, 136: $274-287$

Wallace, J. C. (1972). Activity and metabolic rate in the shore crab Carcinus maenas L. Comp. Biochem. Physiol. $41 \mathrm{~A}$ : 523-535

Weymouth, F. W., Crimson, J. M., Hall, V. E., Belding, H. S., Field, J. (1944). Total and tissue respiration in relation to body weight; a comparison of the kelp crab with other crustaceans and with mammals. Physiol. Zoöl. 17: 50-71

Wiens, A. W., Armitage, K. B. (1961). The oxygen consumption of the crayfish Orconectes immunis and Orconectes nais in response to temperature and to oxygen saturation. Physiol. Zoöl. 34: 39-54

Wilde, P. A. W. J. de (1973). A continuous flow apparatus for long-term recording of oxygen uptake in burrowing invertebrates, with some remarks on the uptake in Macoma balthica. Neth. J. Sea Res. 6: 157-162

Winget, R. R. (1969). Oxygen consumption and respiratory energetics in the spiny lobster Panulirus interruptus (Randall). Biol. Bull. mar. biol. Lab., Woods Hole 136: 301-312

Zeuthen, E. (1953). Oxygen uptake as related to body size in organisms Q. Rev. Biol. 28: 1-12 